\title{
The Effect of Green Manure and \\ Chromolaena-Odorata-Based Bokashi on Nutrient Soil Content and Maize Growth
}

\author{
Jusna Ahmad $^{1}$ (Corresponding Author), Chairunnisa Lamangantjo ${ }^{2}$ \\ Department of Biology, Universitas Negeri Gorontalo \\ J1. Jenderal Sudirman No. 6, Gorontalo, Indonesia \\ jusnakahmad@gmail.com¹, chairunnisahj1@gmail.com² \\ Correspondence email: ahmadjusna02@gmail.com
}

Received: May 28, 2018

doi:10.5296/jas.v6i3.13199
Accepted: June 19, 2018

URL: https://doi.org/10.5296/jas.v6i3.13199

\begin{abstract}
The objectives of this study are twofold; firstly, it is intended to determine the soil nutrient contents (e.g., nitrogen, phosphor, potassium, manganese, and magnesium) after the provision of Chromolaena odorata organic fertilizer. Secondly, the study is aimed at examining the growth of maize crops after the provision of the same fertilizer. It employed randomized design group consisting of three phases of treatment (i.e., control, fertilizer provision, and provision of Bokashi with Chromolaena odorata) and four-times of the repeating process. Furthermore, the variable consists of the contents of soil nutrient before applying the treatment, vegetative growth (i.e., stem height, stem diameter, leaf size, and dry weight of root, stem, and leaf), and generative growth (i.e., weight of unhusked cob, weight of husked cob, number of seeds per cob, width of cob, and weight of 100 seeds). The data were analyzed by using analysis of variance (ANOVA) and it further examined by employing Least Significance Difference test at 5\% level. The results reveal that the provision of Bokashi fertilizer (with Chromolaena odorata as the material) positively impacts the growth of maize crops rather than the provision of green manure and control fertilizer.
\end{abstract}

Keywords: Generative Growth, Organic Fertilizer, Vegetative Growth 


\section{Introduction}

Soil fertility, pest infection and plant diseases are the issues for maize farmers in improving the production of maize. Normally, the farmers use fertilizer and synthetic pesticide to tackle such problems without considering the side effects of using such chemicals.

The use of synthetic fertilizer and pesticides is considered a dilemma for the farmers since it similar with a two-edged sword; these materials are essential to food supplies while the materials are also harmful since it impacts the structure of soil and reduces the soil fertility. Mangkodihardja (as cited in Adriyani, 2006) points out that the dispersion of synthetic pesticide is high; it can reach the percentage $100 \%$. Producing organic fertilizer and pesticide from plants containing compounds that can retain the quality of the soil is able to minimize the risk of using synthetic materials.

Chromolaena odorata is among the plants used as a material for organic fertilizer or pesticide. This plant grows everywhere; it grows particularly well at highland. Despite that the plants are easy to find, people know almost nothing that Chromolaena odorata is beneficial for the agricultural activities. Chromolaena odorata (L.) (R.M King \& H. Rob.) contains considerably high soil nutrients (e.g., $21.94 \% \mathrm{~N}, 0.60 \% \mathrm{P}$, and $1.58 \% \mathrm{~K}$ ); it is also considered as biomass holding the potential to restore the soil fertility. This further improves the growth of the plant.

The benefits of Chromolaena odorata as organic pesticide and fertilizer are little known to most of the farmers in Gorontalo by which they are yet to benefit from the plant. On top of that, they consider the plant as just ordinary weeds. Therefore, developing Chromolaena odorata as an organic fertilizer is necessary to help the farmers examining the effect of this material on the growth of crops, specifically maize.

This study focuses on the development of the weeds as organic material or the basic material for organic fertilizer Bokashi for the farmers to use to enhance the soil fertility; the effect of this fertilizer to maize crops is further examined as well. It is expected that the awareness of the farmers to use organic fertilizer by maximizing the use of natural resources is increased through this study. Moreover, the objectives of this present study are to examine the biomass and the growth of maize crops provided with Chromolaena odorata fertilizer and to analyze the contents of soil nutrients after the provision of the same fertilizer and green manure.

\section{Materials and Methods}

The research materials are Chromolaena odorata, maize crops "Bisi-2" variety, EM4, molasses, bran, cattle dung, and rice straws. Furthermore, this research employed randomized design group consisting of three phases of treatment (i.e., control, fertilizer provision, and provision of Bokashi with Chromolaena odorata) and four-times of the repeating process. Furthermore, the variable consists of the contents of soil nutrient before applying the treatment, vegetative growth (i.e., stem height, stem diameter, leaf dimension, and dry weight of root, stem, and leaf), and generative growth (i.e., weight of unhusked cob, weight of husked cob, number of seeds per cob, width of cob, and weight of 100 seeds). The data were analyzed by using analysis of variance (ANOVA) and it further examined by employing 
Least Significance Difference test at $5 \%$ level. This study was conducted at Bone Bolango regency, on $500 \mathrm{~m} 2$ land which was divided into 12 experiment spaces with 2 x $4 \mathrm{~m} 2$ width for each space. Other analyses were conducted at different sites, i.e., PTPG Laboratory, Tolangohula (analysis of soil nutrients contents), Food Technology Research Center or Balai Pengkajian Teknologi Makanan laboratory (water content analysis), and Botanical laboratory Universitas Negeri Gorontalo (vegetative growth analysis).

\section{Results and Discussion}

\subsection{Analysis of Soil Nutrients}

This present study is aimed at examining the effect of the provision of green manure and Chromolaena odorata Bokashi on the nutrient soil contents. The results of soil nutrient contents are provided in Table 1 as follows.

Table 1. Analysis of soil nutrients contents before and after the provision of green manure and Chromolaena odorata bokashi

\begin{tabular}{|c|c|c|c|c|c|}
\hline \multirow{2}{*}{ No. } & \multirow{2}{*}{ Sample Code } & \multicolumn{4}{|c|}{ Analysis Results } \\
\cline { 3 - 6 } & & Pre-Planting & \multicolumn{3}{|c|}{ Post-Planting } \\
\cline { 4 - 6 } & & Green Manure & Bokashi & Control Fertilizer \\
\hline 1. & C-Organic (\%) & 0.87 & 0.99 & 1.08 & 1.00 \\
\hline 2. & Nitrogen (\%) & 0.13 & 0.13 & 0.16 & 0.15 \\
\hline 3. & P2O5 (ppm) & 55 & 55 & 109 & 58 \\
\hline 4. & K2O (ppm) & 214 & 402 & 489 & 448 \\
\hline 5. & $\mathrm{Mn}(\mathrm{ppm})$ & 0.20 & 0.68 & 0.74 & 0.25 \\
\hline
\end{tabular}

The results reveal that there is no difference in the soil organic matter, consisting of Nitrogen and Manganese, of pre and post-treatment. This phenomenon is closely related to the soil nutrients contents within the Chromolaena odorata. The nutrients are well-known for containing a high level of several compounds, e.g., N, P, and K which also serve as the basic materials of organic fertilizer. However, there is no difference regarding the content of the compounds $\mathrm{C}, \mathrm{N}$, and $\mathrm{Mn}$ in pre and post-treatment; this is due to the characteristics of each compound. In response to this, Wijaya (2008) argues that the content of soil nutrients is formed through some processes, such as mineralization, soil weathering, and decomposition of soil particles. However, these processes are unable to balance the loss of soil nutrients due to the situation where the residue of the agricultural production does not remain in the crop fields. 
Based on the analysis, the characteristic of $\mathrm{N}$ compound, which further mineralized into NO3, is the factor of the low level of this compound. Yet, the unstable nature of Nitrite contained in the soil will be washed away from the root zone in a certain period (in barren conditions or during high rainfall period). To maintain the content of nitrite, planting alternate crops or applying relay cropping or polyculture with two or three plants with varied rooting depths.

\subsection{Vegetative Growth Parameter}

\subsubsection{Width of Crops}

The following Table 2 shows the measurement of the maize crops in terms of the average results of each treatment in different periods (i.e., 25, 35, and 45 days after planting).

Table 2. Average stem width $(\mathrm{cm})$ of maize crops on each treatment

\begin{tabular}{|l|c|c|c|}
\hline \multirow{2}{*}{ TREATMENT } & \multicolumn{3}{|c|}{ AVERAGE STEM WIDTH (cm) } \\
\cline { 2 - 4 } & 25 days after planting & 35 days after planting & 45 days after planting \\
\hline Control Fertilizer & 35 & 111.1 & 225.3 \\
\hline Green Manure & 38.4 & 131.5 & 242.9 \\
\hline Bokashi & 44.1 & 145 & 258.8 \\
\hline
\end{tabular}

The results of ANOVA test reveal that each treatment significantly affects the growth of the stem of crops on day 25, 35, and 45 after planting. Least Significance Difference test on level $5 \%$ is further conducted to examine the effects of each treatment. The results of the test are shown in Table 3.

Table 3. Results of least significance difference test on each treatment

\begin{tabular}{|l|l|l|l|l|l|l|l|l|l|l|l|l|}
\hline \multirow{2}{*}{ Treatment } & \multicolumn{8}{|c|}{ Average Stem Width (in cm) } \\
& \multicolumn{8}{|c|}{ during Observation } \\
\cline { 2 - 12 } & 25 days after planting & \multicolumn{8}{c|}{35 days after planting } & \multicolumn{3}{c|}{45 days after planting } \\
\hline Control Fertilizer & $35^{\mathrm{a}}$ & $35^{\mathrm{a}}$ & $31^{\mathrm{a}}$ & $40^{\mathrm{b}}$ & $12^{\mathrm{c}}$ & $10^{0 \mathrm{a}}$ & $105^{\mathrm{a}}$ & $118^{\mathrm{b}}$ & $237^{\mathrm{b}}$ & $214^{\mathrm{a}}$ & $226^{\mathrm{a}}$ & $224^{\mathrm{a}}$ \\
\hline Green Manure & $41^{\mathrm{b}}$ & $38^{\mathrm{b}}$ & $40^{\mathrm{b}}$ & $35^{\mathrm{a}}$ & $124^{\mathrm{c}}$ & $127^{\mathrm{c}}$ & $130^{\mathrm{c}}$ & $145^{\mathrm{e}}$ & $258^{\mathrm{e}}$ & $242^{\mathrm{b}}$ & $240^{\mathrm{b}}$ & $232^{\mathrm{a}}$ \\
\hline Bokashi & $43^{\mathrm{c}}$ & $40^{\mathrm{b}}$ & $43^{\mathrm{c}}$ & $51^{\mathrm{d}}$ & $140^{\mathrm{d}}$ & $151^{\mathrm{f}}$ & $144^{\mathrm{e}}$ & $145^{\mathrm{e}}$ & $260^{\mathrm{f}}$ & $272^{\mathrm{g}}$ & $250^{\mathrm{c}}$ & $253^{\mathrm{d}}$ \\
\hline
\end{tabular}

Description: Number followed by a letter does not indicate a significant difference.

Factors, e.g., other soil nutrients and sufficient water supplies also affect the increase of crops width; this resonates to the results seen in Nugroho (2015). Nitrogen is particularly a 
compound that helps the growth of stem and leaf. Moreover, sufficient supply of this compound in the soil helps photosynthesize and increase the results of the process. This further advances the growth of the crops. Environmental aspect, i.e., sunlight exposure also contributes to this process.

\subsubsection{Stem Diameter}

The results of average stem diameter on each treatment are shown in Table 4 as follows.

Table 4. Average stem diameter $(\mathrm{cm})$ of maize crops on each treatment

\begin{tabular}{|l|c|c|c|}
\hline \multirow{2}{*}{ TREATMENT } & \multicolumn{3}{|c|}{ AVERAGE STEM DIAMETER (cm) } \\
\cline { 2 - 4 } & 25 days after planting & 35 days after planting & 45 days after planting \\
\hline Control Fertilizer & 0.8 & 2.2 & 2.3 \\
\hline Green Manure & 1.2 & 2.7 & 2.8 \\
\hline Bokashi & 1.4 & 2.9 & 3.2 \\
\hline
\end{tabular}

Least Significance Difference test on level 5\% is further conducted to examine the effects of each treatment. The results of the test are shown in Table 5 as follows.

Table 5. Results of least significance difference test on each treatment

\begin{tabular}{|l|c|c|c|c|c|c|c|c|c|c|c|c|}
\hline \multirow{2}{*}{ Treatment } & \multicolumn{8}{|c|}{ Average Stem Diameter (cm) during Observation } \\
\cline { 2 - 12 } & \multicolumn{3}{|c|}{25 days after planting } & \multicolumn{3}{|c|}{35 days after planting } & \multicolumn{3}{|c|}{ 45 days after planting } \\
\hline $\begin{array}{l}\text { Control } \\
\text { Fertilizer }\end{array}$ & $0.89^{\mathrm{a}}$ & $0.8^{\mathrm{a}}$ & $0.64^{\mathrm{a}}$ & $0.95^{\mathrm{b}}$ & $2.23^{\mathrm{a}}$ & $2.16^{\mathrm{a}}$ & $2.23^{\mathrm{a}}$ & $2.23^{\mathrm{a}}$ & $2.32^{\mathrm{a}}$ & $2.23^{\mathrm{a}}$ & $2.29^{\mathrm{a}}$ & $2.39^{\mathrm{b}}$ \\
\hline $\begin{array}{l}\text { Green } \\
\text { Manure }\end{array}$ & $1.43^{\mathrm{g}}$ & $1.05^{\mathrm{b}}$ & $1.21^{\mathrm{a}}$ & $1.11^{\mathrm{c}}$ & $2.55^{\mathrm{b}}$ & $2.61^{\mathrm{b}}$ & $2.61^{\mathrm{b}}$ & $2.87^{\mathrm{c}}$ & $2.71^{\mathrm{c}}$ & $2.93^{\mathrm{d}}$ & $2.87^{\mathrm{d}}$ & $2.87^{\mathrm{d}}$ \\
\hline Bokashi & $1.34^{\mathrm{1}}$ & $1.27^{\mathrm{e}}$ & $1.37^{\mathrm{1}}$ & $1.59^{\mathrm{n}}$ & $2.87^{\mathrm{c}}$ & $3.02^{\mathrm{c}}$ & $3.02^{\mathrm{c}}$ & $2.87^{\mathrm{c}}$ & $3.18^{\mathrm{e}}$ & $3.18^{\mathrm{e}}$ & $3.12^{\mathrm{e}}$ & $3.18^{\mathrm{e}}$ \\
\hline
\end{tabular}

Description: Number followed by a letter does not indicate a significant difference

The widest stem diameter is the maize crops with Bokashi treatment, followed by the crops with green manure. This is because the nutrients within Bokashi support the vegetative growth of the crops.

\subsubsection{Leaf Sizes}

The average results of the measurement of the leaf on each treatment are provided in the following Table 5 . 
Table 5. Average results of leaf sizes $\left(\mathrm{cm}^{2}\right)$ on each treatment

\begin{tabular}{|l|c|c|c|c|c|}
\hline \multirow{2}{*}{ TREATMENT } & \multicolumn{5}{|c|}{ AVERAGE LEAF SIZE $\left(\mathrm{cm}^{2}\right)$} \\
\cline { 2 - 6 } & $\begin{array}{l}5 \text { days } \\
\text { after } \\
\text { planting }\end{array}$ & $\begin{array}{l}15 \text { days } \\
\text { after } \\
\text { planting }\end{array}$ & $\begin{array}{l}25 \text { days } \\
\text { after } \\
\text { planting }\end{array}$ & $\begin{array}{l}35 \text { days } \\
\text { after } \\
\text { planting }\end{array}$ & $\begin{array}{l}\text { 45 days } \\
\text { after } \\
\text { planting }\end{array}$ \\
\hline $\begin{array}{l}\text { Control } \\
\text { Fertilizer }\end{array}$ & 8.1 & 35.2 & 457.3 & 721.2 & 724.1 \\
\hline Green Manure & 10.9 & 61.4 & 459.1 & 799 & 802.2 \\
\hline Bokashi & 10.1 & 67.6 & 449 & 860.1 & 873.2 \\
\hline
\end{tabular}

Table 5 shows that the increase in leaf size is directly proportional to the age of vegetative growth of maize crops. The increase of leaf sizes on day 35 to 45 after planting is a bit slower due to the fact that the vegetative growth of the crops has reached its max.

Least Significance Difference test on level 5\% is further conducted to examine the different effects of each treatment. The results of the test are shown in Table 6 as follows.

Table 6. Results of least significance difference test on each treatment

\begin{tabular}{|l|l|l|l|l|l|l|l|l|l|l|l|l|}
\hline \multirow{2}{*}{ Treatment } & \multicolumn{7}{|c|}{ Average Leaf Sizes/During Observation } \\
\cline { 2 - 12 } & \multicolumn{7}{|c|}{15 days after planting } & \multicolumn{2}{|l|}{35 days after planting } & \multicolumn{3}{|c|}{45 days after planting } \\
\hline Control Fertilizer & $38^{\mathrm{b}}$ & $37^{\mathrm{b}}$ & $45^{\mathrm{b}}$ & $21^{\mathrm{a}}$ & $696^{\mathrm{a}}$ & $728^{\mathrm{a}}$ & $750^{\mathrm{a}}$ & $712^{\mathrm{a}}$ & $695^{\mathrm{a}}$ & $731^{\mathrm{a}}$ & $750^{\mathrm{a}}$ & $721^{\mathrm{a}}$ \\
\hline Green Manure & $62^{\mathrm{d}}$ & $59^{\mathrm{d}}$ & $64^{\mathrm{d}}$ & $61^{\mathrm{d}}$ & $756^{\mathrm{b}}$ & $787^{\mathrm{c}}$ & $789^{\mathrm{c}}$ & $866^{\mathrm{d}}$ & $760^{\mathrm{b}}$ & $789^{\mathrm{c}}$ & $790^{\mathrm{c}}$ & $870^{\mathrm{d}}$ \\
\hline Bokashi & $58^{\mathrm{c}}$ & $65^{\mathrm{d}}$ & $71^{\mathrm{d}}$ & $76^{\mathrm{e}}$ & $859^{\mathrm{d}}$ & $861^{\mathrm{d}}$ & $859^{\mathrm{d}}$ & $862^{\mathrm{d}}$ & $865^{\mathrm{d}}$ & $869^{\mathrm{d}}$ & $886^{\mathrm{d}}$ & $871^{\mathrm{d}}$ \\
\hline
\end{tabular}

Description: Number followed by a letter does not indicate a significant difference.

The above table shows that the provision of Bokashi gives the best results in terms of the leaf sizes. The nitrogen compound within Bokashi is able to support the growth of the leaf. This resonates to Wijaya's argument (2008) that the provision of the compound advances the growth of parts of crops which are responsible for photosynthesizing. Furthermore, crops with sufficient supply of compound $\mathrm{N}$ will form the larger size of leaves containing a high level of chlorophyll which enables the crops to produce carbohydrate or assimilate in a plentiful amount to support the vegetative growth.

\subsubsection{Dry Weight of Root, Stem, and Leaf}

The results of average measurement of the dry weight of several parts, i.e., root, stem, and leaves on each treatment are shown in Table 7 as follows. 
Table 7. Average dry weight of root, stem, and leaf on each treatment

\begin{tabular}{|l|c|c|c|c|c|}
\hline \multirow{2}{*}{ TREATMENT } & \multicolumn{5}{|c|}{$\begin{array}{c}\text { AVERAGE DRY WEIGHT OF ROOT, STEM, } \\
\text { AND LEAF (Gram) }\end{array}$} \\
\cline { 2 - 6 } & $\begin{array}{l}5 \text { days } \\
\text { after } \\
\text { planting }\end{array}$ & $\begin{array}{l}\text { 15 days } \\
\text { after } \\
\text { planting }\end{array}$ & $\begin{array}{l}\text { 25 days } \\
\text { after } \\
\text { planting }\end{array}$ & $\begin{array}{l}\text { 35 days } \\
\text { after } \\
\text { planting }\end{array}$ & $\begin{array}{l}\text { 45 days } \\
\text { after } \\
\text { planting }\end{array}$ \\
\hline $\begin{array}{l}\text { Control } \\
\text { Fertilizer }\end{array}$ & 0.06 & 0.6 & 37.9 & 79.1 & 80 \\
\hline Green Manure & 0.1 & 1.1 & 42.7 & 101.4 & 111 \\
\hline Bokashi & 0.2 & 1.2 & 48.6 & 126.8 & 147.9 \\
\hline
\end{tabular}

Least Significance Difference test on level 5\% is further conducted to examine the effects of each treatment. The results of the test are shown in Table 8 as follows.

Table 8. Results of least significance different test of average dry weight of root, stem, and leaf on each treatment

\begin{tabular}{|c|c|c|c|c|c|c|c|c|c|c|c|c|}
\hline \multirow[t]{2}{*}{ Treatment } & \multicolumn{12}{|c|}{$\begin{array}{l}\text { Average Dry Weight of Root, Stem, } \\
\text { and Leaf/During Observation }\end{array}$} \\
\hline & \multicolumn{4}{|c|}{5 days after planting } & \multicolumn{4}{|c|}{15 days after planting } & \multicolumn{4}{|c|}{$\begin{array}{l}25 \text { days after } \\
\text { planting }\end{array}$} \\
\hline $\begin{array}{l}\text { Control } \\
\text { Fertilizer }\end{array}$ & $0.08^{\mathrm{a}}$ & $0.06^{\mathrm{a}}$ & $0.05^{\mathrm{a}}$ & $0.05^{\mathrm{a}}$ & $0.67^{b}$ & $0.64^{b}$ & $0.75^{b}$ & $0.34^{\mathrm{a}}$ & $38^{\mathrm{a}}$ & $41^{b}$ & $37^{\mathrm{a}}$ & $36^{\mathrm{a}}$ \\
\hline $\begin{array}{l}\text { Green } \\
\text { Manure }\end{array}$ & $0.12^{\mathrm{c}}$ & $0.10^{\mathrm{b}}$ & $0.11^{\mathrm{c}}$ & $0.11^{\mathrm{c}}$ & $1.03^{\mathrm{c}}$ & $1.17^{\mathrm{d}}$ & $1.13^{\mathrm{d}}$ & $0.88^{\mathrm{b}}$ & $45^{\mathrm{d}}$ & $42^{b}$ & $41^{\mathrm{b}}$ & $43^{c}$ \\
\hline Bokashi & $0.21^{\mathrm{e}}$ & $0.13^{\mathrm{d}}$ & $0.14^{\mathrm{d}}$ & $0.13^{\mathrm{d}}$ & $1.20^{\mathrm{e}}$ & $1.44^{\mathrm{f}}$ & $1.18^{\mathrm{e}}$ & $1.10^{\mathrm{d}}$ & $47^{\mathrm{e}}$ & $51^{\mathrm{g}}$ & $50^{\mathrm{f}}$ & $47^{\mathrm{e}}$ \\
\hline
\end{tabular}

Table 8. Cont'd

\begin{tabular}{|c|r|r|r|r|r|r|r|r|}
\hline \multirow{2}{*}{ Treatment } & \multicolumn{6}{|c|}{ Average Dry Weight of Root, Stem, and Leaf/During Observation } \\
\cline { 2 - 9 } & \multicolumn{3}{|c|}{35 days after planting } & \multicolumn{4}{|c|}{45 days after planting } \\
\hline Control Fertilizer & $77^{\mathrm{a}}$ & $73^{\mathrm{a}}$ & $80^{\mathrm{a}}$ & $87^{\mathrm{a}}$ & $70^{\mathrm{a}}$ & $75^{\mathrm{a}}$ & $82^{\mathrm{b}}$ & $81^{\mathrm{b}}$ \\
\hline Green Manure & $100^{\mathrm{c}}$ & $96^{\mathrm{b}}$ & $99^{\mathrm{c}}$ & $112^{\mathrm{d}}$ & $107^{\mathrm{c}}$ & $104^{\mathrm{c}}$ & $119^{\mathrm{d}}$ & $114^{\mathrm{c}}$ \\
\hline Bokashi & $146^{\mathrm{f}}$ & $123^{\mathrm{e}}$ & $120^{\mathrm{e}}$ & $118^{\mathrm{e}}$ & $140^{\mathrm{e}}$ & $150^{\mathrm{e}}$ & $149^{\mathrm{e}}$ & $153^{\mathrm{f}}$ \\
\hline
\end{tabular}




\section{Al Macrothink}

The provision of fertilizer with $\mathrm{N}$ compound is able to improve the concentration of phosphorus within the crops; it further stimulates the growth of the root by which it enhances the absorption capacity and its speed in absorbing soil nutrients (Fahmi et al., 2010). Enhanced soil nutrients absorption by the root automatically affect the growth of stem and leaves by which it increases the dry weight of a plant. The increase of the weight indicates that the soil nutrients are sufficiently supplied.

\subsection{Generative Growth Parameter}

\subsubsection{Weight of Unhusked Cob}

The average results of the measurement of the unhusked cob on each treatment are provided in the following Table 9.

Table 9. Average weight of unhusked cob (gr) on each treatment

\begin{tabular}{|c|c|}
\hline TREATMENT & $\begin{array}{c}\text { AVERAGE WEIGHT OF CROPS WITH } \\
\text { UNHUSKED COB (gr) }\end{array}$ \\
\hline CONTROL FERTILIZER & 205.7 \\
\hline GREEN MANURE & 217.9 \\
\hline BOKASHI & 220.1 \\
\hline
\end{tabular}

The results of ANOVA test on determining the effect of treatment (i.e., the provision of control fertilizer, green manure, and Bokashi) reveal a significant influence towards the weight of unhusked cob of maize crops. Least Significance Difference test on level 5\% is further conducted to examine the effects of each treatment. The results of the test are shown in Table 5 as follows.

Table 10. Results of least significance difference test on each treatment

\begin{tabular}{|c|c|c|c|c|}
\hline & \multicolumn{4}{|c|}{ AVERAGE WEIGHT } \\
TREATMENT & \multicolumn{3}{|c|}{ Of UNHUSKED COB (GR) $^{\mathrm{b}}$} \\
\hline CONTROL FERTILIZER & $213.1^{\mathrm{b}}$ & $190^{\mathrm{a}}$ & $201.7^{\mathrm{a}}$ & $217.8^{\mathrm{c}}$ \\
\hline GREEN MANURE & $217.5^{\mathrm{c}}$ & $221.8^{\mathrm{c}}$ & $218.6^{\mathrm{c}}$ & $215.8^{\mathrm{b}}$ \\
\hline BOKASHI & $224.4^{\mathrm{c}}$ & $220.5^{\mathrm{c}}$ & $235.8^{\mathrm{d}}$ & $225.1^{\mathrm{c}}$ \\
\hline
\end{tabular}

Description: Number followed by a letter does not indicate a significant difference.

It is believed that the weight of unhusked cob is determined by the size of the cob and seed of maize crops. This is echoing the results seen in Utama et al. (2013) that the best growth of maize crops is the contributing factor of several processes, such as flowering, cob forming, and seeds filling; it results in an increase in the weight of the cob. 


\section{Macrothink}

On day 33 to 55 after the crop begins to germinate, the crops grow faster and so as the accumulation process of the dry materials. Soil nutrients and water supply are indispensable to advance the growth of crops. Plants are sensitive to drought and lacking soil nutrients by which it affects the growth of the cob.

On top of that, such conditions reduce the number of seeds per cob due to smaller cob size. This results in a drop in the production of the crops (Subekti et al., 2002).

\subsubsection{Husked Cob Weight}

The average results of the measurement of the weight husked cob on each treatment are provided in the following Table 11.

Table 11. Average weight of husked cob on each treatment

\begin{tabular}{|c|c|}
\hline TREATMENT & $\begin{array}{c}\text { AVERAGE WEIGHT } \\
\text { OF HUSKED COB }\end{array}$ \\
\hline CONTROL FERTILIZER & 142.8 \\
\hline GREEN MANURE & 156.8 \\
\hline BOKASHI & 179 \\
\hline
\end{tabular}

The results of ANOVA test in determining the effect of treatment reveal a significant influence towards the weight of unhusked cob of maize crops. Least Significance Difference test on level $5 \%$ is further conducted to examine the different effects of each treatment. The results of the test are shown in Table 12 as follows.

Table 12. Results of least significance difference test on each treatment

\begin{tabular}{|c|c|c|c|c|}
\hline TREATMENT & \multicolumn{4}{|c|}{$\begin{array}{l}\text { AVERAGE WEIGHT } \\
\text { OF HUSKED COB }\end{array}$} \\
\hline CONTROL FERTILIZER & $152.3^{b}$ & $120^{\mathrm{a}}$ & $131.4^{\mathrm{a}}$ & $167.6^{\mathrm{c}}$ \\
\hline GREEN MANURE & $136.9^{\mathrm{a}}$ & $169.3^{\mathrm{d}}$ & $160.4^{b}$ & $160.4^{b}$ \\
\hline BOKASHI & $199.2^{\mathrm{e}}$ & $172.1^{\mathrm{d}}$ & $164.7^{\mathrm{c}}$ & $179.9^{d}$ \\
\hline
\end{tabular}

During seed filling, maize crops require compound N and P in which Sirappa and Rajak point out that these compounds will be absorbed until the crops are ripening while compound $\mathrm{K}$ is essential in the silking process. These compounds flow to some growing parts of crops, e.g., stem, leaves, stamen (male flowers), and seeds. Nurhayati (2002) asserts that the increased weight of the maize cob is closely related to the results of photosynthesizing flowed into this part. The higher the results of photosynthesize flow to the cob, the bigger the maize cob. 


\subsubsection{Total Seeds per Cob}

The average results of the seeds per cob on each treatment are provided in the following Table 13.

Table 13. Total seeds per cob on each treatment

\begin{tabular}{|c|c|}
\hline & AVERAGE \\
TREATMENT & TOTAL SEEDS PER COB \\
\hline CONTROL FERTILIZER & 374.7 \\
\hline GREEN MANURE & 417.6 \\
\hline BOKASHI & 460.2 \\
\hline
\end{tabular}

Table 13 shows the number of maize seeds per cob which is different on each treatment.

The results of ANOVA test in determining the effect of treatment reveal a significant influence towards the seed amount per cob. Least Significance Difference test on level 5\% is further conducted to examine the different effects of each treatment. The results of the test are shown in Table 14 as follows.

Table 14. Results of least significance difference test on each treatment

\begin{tabular}{|c|c|c|c|c|}
\hline TREATMENT & \multicolumn{4}{|c|}{ TOTAL SEEDS PER COB $^{\mathrm{a}}$} \\
\hline CONTROL FERTILIZER & $384^{\mathrm{b}}$ & $364^{\mathrm{a}}$ & $327^{\mathrm{a}}$ & $424^{\mathrm{c}}$ \\
\hline GREEN MANURE $^{\mathrm{b}}$ & $417^{\mathrm{b}}$ & $437^{\mathrm{c}}$ & $408^{\mathrm{b}}$ & $408^{\mathrm{b}}$ \\
\hline BOKASHI & $481^{\mathrm{f}}$ & $420^{\mathrm{c}}$ & $467^{\mathrm{d}}$ & $473^{\mathrm{e}}$ \\
\hline
\end{tabular}

Description: Number followed by a letter does not indicate a significant difference

\subsubsection{Width of Cob}

The measurement of the width of the cob on each treatment is provided in the following Table 15.

Table 15. Average width of cob of maize crops on each treatment

\begin{tabular}{|c|c|}
\hline TREATMENT & AVERAGE WIDTH OF COB $(\mathrm{cm})$ \\
\hline CONTROL FERTILIZER & 17.4 \\
\hline GREEN MANURE & 18.6 \\
\hline BOKASHI & 19.5 \\
\hline
\end{tabular}




\section{Ml Macrothink}

The ANOVA test shows a significant effect towards the width of maize cob. Least Significance Difference test on level 5\% is further conducted to examine the effects of each treatment. The results of the test are shown in Table 16 as follows.

Table 16. Results of least significance difference test on each treatment

\begin{tabular}{|c|c|c|c|c|}
\hline TREATMENT & \multicolumn{4}{|c|}{ AVERAGE WIDTH OF COB } \\
\hline CONTROL FERTILIZER & $18^{\mathrm{b}}$ & $16.2^{\mathrm{a}}$ & $17.1^{\mathrm{a}}$ & $18.1^{\mathrm{b}}$ \\
\hline GREEN MANURE $^{\mathrm{c}} 19.1^{\mathrm{c}}$ & $18.2^{\mathrm{b}}$ & $18.6^{\mathrm{c}}$ & $18.4^{\mathrm{c}}$ \\
\hline BOKASHI & $19.8^{\mathrm{e}}$ & $19.2^{\mathrm{d}}$ & $18.9^{\mathrm{c}}$ & $20^{\mathrm{e}}$ \\
\hline
\end{tabular}

Description: Number followed by a letter does not indicate a significant difference.

The best result of cob size parameter is on the crops with the provision of Bokashi. It is supported by the result of analysis of soil nutrients in pre and post-treatment; the compound Mn has undergone a significant increase. This compound plays a major role in the process of cell division and enlargement. Wijaya (2008) argues that deficiency of compound Mn affects cell enlargement the most rather than cell division. In other words, cell enlargement impacts on the growth of the cob size. Deficiency of Mn compounds leads to a condition where stomata are closed. This further blocks the transpiration by which it inhibits the crops to absorb passive-moving compounds or elements, i.e., $\mathrm{N}$ and $\mathrm{Ca}$ that follow the water flow.

\subsubsection{Weight of 100 Maize Seeds}

The average results of the accumulation of 100 seeds on each treatment are provided in the following Table 17.

Table 17. Average weight of 100 maize seeds on each treatment

\begin{tabular}{|c|c|}
\hline TREATMENT & AVERAGE WEIGHT OF 100 MAIZE SEEDS (gr) \\
\hline CONTROL FERTILIZER & 32 \\
\hline GREEN MANURE & 32.7 \\
\hline BOKASHI & 35.4 \\
\hline
\end{tabular}

Table 17 shows that there is no significant difference in terms of the number of each treatment.

Least Significance Difference test on level 5\% is further conducted to examine the effects of each treatment. The following Table 18 shows the results of the test. 
Table 18. Results of least significance difference test on each treatment

\begin{tabular}{|c|c|c|c|c|}
\hline TREATMENT & \multicolumn{4}{|c|}{ AVERAGE WEIGHT OF 100 MAIZE SEEDS } \\
\hline CONTROL FERTILIZER & $33.5^{\mathrm{b}}$ & $30.1^{\mathrm{a}}$ & $32^{\mathrm{a}}$ & $30.5^{\mathrm{a}}$ \\
\hline GREEN MANURE & $31.4^{\mathrm{a}}$ & $34.1^{\mathrm{c}}$ & $33^{\mathrm{b}}$ & $32.2^{\mathrm{a}}$ \\
\hline BOKASHI & $37^{\mathrm{f}}$ & $35^{\mathrm{e}}$ & $34.5^{\mathrm{d}}$ & $35.1^{\mathrm{e}}$ \\
\hline
\end{tabular}

Description: Number followed by a letter does not indicate a significant difference.

Crops with the provision of Bokashi show better results in terms of the weight of 100 maize seeds. It is related to the complexity of materials of Bokashi consisting of Chromolaena odorata. This plant contains some compounds, such as $\mathrm{P}$ and $\mathrm{K}$, useful for supplying soil nutrients required for generative phase. In response to this, Rahimi et al. (2013) add that the weight of seed depends on the content of dry materials within the seed. These materials (obtained from the result of photosynthesizing) are used for the process of seed filling.

\section{Conclusion}

The study concludes that the provision of green manure and Bokashi with Chromolaena odorata promotes the soil nutrients quality and also leads to better soil texture and fertility. The provision of green manure and Bokashi with Chromolaena odorata contributes to the vegetative growth of maize crops, i.e., leaf sizes, leaf amount, stem width, stem diameter, and dry weight of root, stem, and leaf. The provision of green manure and Bokashi with Chromolaena odorata contributes to the generative growth of maize crops, i.e., the weight of husked and unhusked cob, amount of seed per cob, cob size, and weight of 100 seeds.

\section{Authors' Contribution}

Jusna Ahmad: responsible for research design and data analysis.; Chairunnisa Lamangantjo: participated in data collection and assisted the lead researcher in analyzing the data.

\section{References}

Agaba, A. ., \& Fawole, B. (2016). Phytochemical constituents of siam weed ( Chromolaena Odorata ) and African Custard Apple ( Annona Senegalensis ), 6(1), 35-42.

Alex, S. (2015). Sukses mengolah sampah organik menjadi pupuk organik [Effective methods in processing organic waste into organic fertilizer]. Yogyakarta: Pustaka baru Press.

Amaru, K., Suryadi, E., Bafdal, N., \& Asih, F.P. (2013). Kajian kelembaban tanah dan kebutuhan air beberapa varietas Hibrida DR UNPAD [The study of soil moisture and water needs of some hybrid varieties DR UNPAD]. Bandung: Universitas Padjajaran.

Badan Penyuluhan dan Pengembangan SDM Pertanian. (2015). Pelatihan teknis budidaya jagung bagi penyuluh pertanian dan babinsa-pemupukkan jagung [Technical training of corn cultivation for agricultural extension practitioner and NCO village builder-maize fertilizer]. Pusat Pelatihan Pertanian. 
Birnadi, S. (2014). Pengaruh pengolahan tanah dan pupuk organik bokashi terhadap pertumbuhan dan hasil tanaman kedelai (Glycine max L.) [The effect of land processing and the provision of organic fertilizer bokashi on growth and soybean products (Glycine max L.)], Kultivar Wilis. UIN SGD Bandung, 7(1), 159-181.

Damayanti, N. (2012). Perkecambahan dan pertumbuhan sawi hijau (Brassica rapa L. var. parachinensis L.H. Bailey) setelah pemberian ekstrak kirinyuh (Chromolaena odorata (L) R.M. King \& H. Rob.). [Germination and growth of (Brassica rapa L. var. parachinensis L.H. Bailey) after the provision of Chromolaena odorata (L) R.M. King \& H. Rob.) Extract]. Surakarta: Universitas Sebelas Maret.

Djaenudin D,. Marwan H., Subagjo H., \& Hidayat, A. (2003). Petunjuk teknis evaluasi lahan untuk komoditas pertanian edisi ke-1 [Land-based technical evaluation guide for agricultural commodities, 1st Edition]. Balai Penelitian Tanah, Pusat Penelitian dan Pengembangan Tanah dan Agroklimat. Bogor.

Fahmi, A., Syamsudin., Utami, S.N.H., \& Radjagukguk, B. (2010). Pengaruh interaksi hara nitrogen dan fosfor terhadap pertumbuhan tanaman jagung (Zea mays L) pada tanah regosol dan latosol [The effect of nitrogen and phosphorus interaction on the Growth of Zea mays L on regosol and latosol]. BPPLR Banjarbaru Kalimantan Selatan \& BPPTP Sulawesi Selatan.

Gomez, K. A., \& Gomez, A. A. (1995). Prosedur statistik untuk penelitian pertanian (edisi kedua) [Statistical procedures for agricultural research (second edition)]. Jakarta: UI-Press.

Hayat, E. S., \& Andayani, S. (2014). Pengelolaan limbah tandan kosong kelapa sawit dan aplikasi biomassa Chromolaena odorata serta sifat tanah sulfaquent [Waste palm management of palm oil and biomass applications of Chromolaena odorata and land properties of sulfaquent], 17(2), 44-51.

Martini, E., Ismawan, I. N., Prahmono, A., Surgana, M., Megawati, Suryadi, A., \& Erwin, L. O. M. (2015). Pupuk organik pada budi daya kebun campur [Organic fertilizer on mixed garden cultivation]. World Agroforestry Centre: AgFor Sulawesi.

Nugroho. (2009). Tanaman jagung [Maize crops]. Retrieved on August 16, 2017 from: http://digilib.ump.ac.idfilesdisk114jhptump-a-mastur-686-2-babii.pdf.

Nugroho, W.S. (2015). Penetapan standar warna daun sebagai upaya identifikasi status hara (N) tanaman jagung (Zea mays L.) pada tanah regosol [Stipulation of leaf color standard in identifying the nutritional status $(\mathrm{N})$ of Zea mays L. on regosol land]. Jakarta: PT. Astra Agro Lestari.

Prawiradiputra, B. R. (2007). Chromolaena odorata (L) R.M. King and H. Robinson: Gulma padang rumput yang merugikan [Chromolaena odorata (L) R.M. King and H. Robinson: Harmful weed], 17(1), 46-52.

Riyana, C. (2007). Pedoman pengembangan media video [Video media development guidelines]. Jakarta: P3AI UPI.

Rochani, S. (2007). Bercocok tanam jagung [Maize crops cultivation]. Bandung: Azka Press. 
Rukmana, R. (1997). Usaha tani jagung [Maize farming]. Yogyakarta: Kanisius.

Setyowati, N., Nurjanah, U., \& Haryanti, D. (2008). Gulma tusuk konde (Wedelia trilobata) dan kirinyu (Chlomolaena odorata) sebagai pupuk organik pada sawi (Brassica chinensis L.) [Wedelia trilobata and Chlomolaena odorata as organic fertilizer for Brassica chinensis L)]. Akta Agrosia, 11(1), 47-56.

Simanungkalit, R. D. M., Suriadikarta, D. A., Saraswati, R., Setyorini, D., Hartatik, W., \& Penelitian, B. (2006). Pupuk organik dan pupuk hayati [Organic fertilizer and compost]. Jawa

Subekti, N.A., Syafruddin, R. Efendi, S., \& Sunarti. (2007). Morfologi tanaman dan fase pertumbuhan jagung [Morphology and growth phase of maize]. Maros: Balai Penelitian Tanaman Serealia.

Syafruddin., Suwarti., \& Azrai, M. (2014). Penyaringan cepat dan toleransi tanaman jagung terhadap intensitas cahaya rendah [Rapid screening and tolerance of maize crops to low light intensity]. Sulawesi Selatan: Balai Penelitian Tanaman Serealia. Penelitian Pertanian Tanaman Pangan.

Wahyono, S., Sahwan, F., \& Suryanto, F. (2011). Membuat Pupuk Organik Granul dari Aneka Limbah [The Making of Organic Granular Fertilizer from Various Wastes]. Jakarta: AgroMedia Pustaka.

Wijayanto, N., \& Nurunnajah. (2012). Intensitas cahaya , suhu , kelembaban dan perakaran lateral mahoni ( Swietenia macrophylla King .) di RPH Babakan Madang, BKPH Bogor, $\mathrm{KPH}$ Bogor [Intensity of light, temperature, humidity and lateral rooting of Swietenia macrophylla King. in slaughterhouse Babakan Madang, Forest Caretaker Unit Section, Bogor]. Jurnal Silvikultur Tropika, 3(1), 8-13.

Wijaya, K.A. (2008). Nutrisi tanaman sebagai penentu kualitas hasil dan resistensi alami tanaman [Plant nutrition as a determinant of the quality and natural resistance of plant products]. Jakarta: Prestasi Pustaka Publisher.

\section{Copyright Disclaimer}

Copyright for this article is retained by the author(s), with first publication rights granted to the journal.

This is an open-access article distributed under the terms and conditions of the Creative Commons Attribution license (http://creativecommons.org/licenses/by/4.0/). 